\title{
Oligoneuria macabaiba sp. nov. (Insecta: Ephemeroptera) from Brazil
}

\author{
Inês C. Gonçalves ${ }^{1}$, Elidiomar R. Da-Silva² \& Jorge L. Nessimian ${ }^{3}$
}

1. Universidade Federal do Rio de Janeiro, Instituto de Biologia, Departamento de Zoologia, Laboratório de Entomologia. Avenida Brigadeiro Trompowski, s/n, bloco A, sala 107, Ilha do Fundão, Rio de Janeiro, RJ, Brazil. CEP 21941-971, C. Postal 68044; inescg.bio@gmail.com

2. Universidade Federal do Estado do Rio de Janeiro, Instituto de Biociências, Departamento de Zoologia, Laboratório de Insetos Aquáticos. Av. Pasteur, 458, 4o andar, Urca, Rio de Janeiro, RJ, Brasil CEP 22290-240; elidiomar@pq.cnpq.br

3. Universidade Federal do Rio de Janeiro, Instituto de Biologia, Departamento de Zoologia, Laboratório de Entomologia. Avenida Brigadeiro Trompowski, s/n, bloco A, sala 107, Ilha do Fundão, Rio de Janeiro, RJ, Brazil. CEP 21941-971, C. Postal 68044; nessimia@acd.ufrj.br

Received 12-X-2010. C Corrected 20-II-2011. Accepted 24-III-2011.

\begin{abstract}
The former monotypic genus Oligoneuria Pictet was known solely by a female subimago of the type-species Oligoneuria anomala Pictet. A new species of the genus Oligoneuria from the Atlantic rainforest of Macaé, Rio de Janeiro is described. The description was based in males and females imagos of Oligoneuria macabaiba sp. nov. caught with light traps. This species presents similar wing venation, abdominal posterolateral spines, as well as a membranous extension on anterior portion of the head as seen in the genus. Based on features of the new species, the genus is herein redefined. The species represents the first record of the genus from Southeastern Brazil. Rev. Biol. Trop. 59 (4): 1553-1557. Epub 2011 December 01.
\end{abstract}

Key words: Neotropics, new record, new species, Oligoneuriidae, South America, taxonomy.

The former monotypic genus Oligoneuria Pictet was known solely by a female subimago of the type-species Oligoneuria anomala Pictet. The genus was recently placed as a senior synonym of Oligoneurioides Demoulin by Kluge (2007) and is now composed by three species: $O$. anomala, $O$. amazonica (Demoulin) and O. itayana Kluge. All of these species occur in the Amazonian Rainforest, two with records from Brazil (O. anomala and $O$. amazonica). Analyzing wing venation of $O$. itayana in nymphal protopteron and imagos, Kluge (2007) observed that wing venation of nymphs is much more complete than that seen on winged stages, thus attesting that loss of veins in the winged stages is not of phylogenetic significance, and cannot be used to separate both genera.

A new species of Oligoneuria from Brazil is herein described based on male and female imagos from the Atlantic Rainforest. Despite several attempts, no nymph was found on collecting sites but adult's characteristics are enough to place specimens on this genus. The new species possess the distinctive membranous extension on front of the head and wing venation similar to that of Oligoneuria, but rather different male genitalia. Diagnosis of Oligoneuria is, therefore, altered to comprise this difference. The new species represents the first record of the genus from Southeastern Brazil.

\section{MATERIAL AND METHODS}

Imagos from both sexes where caught on light traps in the municipality of Macaé, Rio de Janeiro State. Specimens were preserved in $80 \%$ ethanol. Males and females were collected 
on same swarm. Searching was made in the Macaé river, but after several attempts nymphs were not found. Interpretation of wing veins was based on Kluge $(2004,2007)$. Type material is deposited at Coleção Entolomógica Professor José Alfredo Pinheiro Dutra (DZRJ) - Departamento de Zoologia, Universidade Federal do Rio de Janeiro (UFRJ). Drawings were made under a stereoscopic microscope with camera lucida. Collecting sites were marked with a GPS using the datum WGS84.

\section{RESULTS}

\section{Oligoneuria macabaiba sp. nov.}

Diagnosis: Oligoneuria macabaiba sp. nov. can be recognized by the following combination of characteristics: (1) hind wings with CuA curved apically; (2) faintly marked cross veins basal to $\mathrm{CuA}$ of hind wing; (3) posterolateral spines on abdominal segment II not well developed, restricted to a small projection; (4) male styliger plate almost rectangular, without well developed posterolateral projections; (5) male genitalia with two divergent sclerotized spines, directed posterolaterally, and a median membranous area, divided into two lobes (as in figure 3 ).

Male Imago (Holotype): Length: body $14.0 \mathrm{~mm}$; fore wing $10.5 \mathrm{~mm}$; hind wing $5.7 \mathrm{~mm}$.

Head: Area between eyes and ocelli whitish suffused with gray. Margins of head black. Head ventrally covered by a membranous black extension. Eyes black. Ocelli white surrounded by black ring at base. Base of antennae whitish; scape whitish possessing incomplete wide blackish ring; pedicel and flagellum brownish.

Thorax: Pronotum whitish; meso and metanota yellowish; terga with scattered brownish stains. Membranous filaments of mesonotum short. Prosternum whitish; meso and metasterna yellowish; sterna with scattered brownish stains.

Wings: Membrane of wings translucent whitish; bearing several microtrichia. Fore wings with cross veins ranging from base to apex of $\mathrm{C}$ and Sc area and from base to almost apex of $R_{1}$ and $R_{3}$ area (Fig. 1). Hind wings with cross veins basally on $\mathrm{C}$ and Sc area and $\mathrm{R}_{1}$ and $\mathrm{R}_{3}$ area. Vein CuA curved apically; faint cross veins present basal to $\mathrm{CuA}$ of hind wing (Fig. 2).

Legs: Forelegs whitish, femora with two brownish longitudinal stripes; tibiae and first two segments of tarsi shaded with brown. Forelegs with three tarsal segments, first two segments same in length, third longer, more than twice the length of first two tarsomeres. Remaining legs with yellowish femora, possessing a brown wide basal band and a narrow apical band; tibiae and last tarsomere of each leg whitish; tibiae with basal mark and inner margin brownish. Mid and hind tarsi with four segments, first and last tarsomeres more than twice as long as second and third tarsomeres together. Tarsal claws blunt.

Abdomen: Posterolateral spines present on segments II-IX; only a small projection on segment II; spines more developed on remaining segments. All spines flexible ("twisted" according to Salles et al. 2007), except those on tergum IX. Terga reddish brown. Terga with median fainted longitudinal line, light colored (Fig. 4). Sterna whitish, shaded with reddish brown.

Genitalia: Styliger plate straight, not projected. Segment I of forceps with inner margin possessing several short setae on apical half. Penes divided into two membranous lobes, each possessing a posterolaterally directed spine on outer margin (Fig. 3). Caudal filaments whitish with brown annulations, subequal in length, with row of long setae on junctions.

Variations: Length: body $13.0 \mathrm{~mm}-$ $14.6 \mathrm{~mm}$; forewing $10.0 \mathrm{~mm}-10.8 \mathrm{~mm}$; hind wing $5.4-5.7 \mathrm{~mm}$. Some specimens showed abdomen completely shaded with reddish brown; terga and sterna suffused with reddish brown, without longitudinal lines (Fig. 4-6).

Female Imago: Length: body $16.0 \mathrm{~mm}$; forewing $14.0 \mathrm{~mm}$; hind wing $6.9 \mathrm{~mm}$.

Similar to males. Legs atrophied; tibiae and tarsi thin and twisted. Posterior margin of 


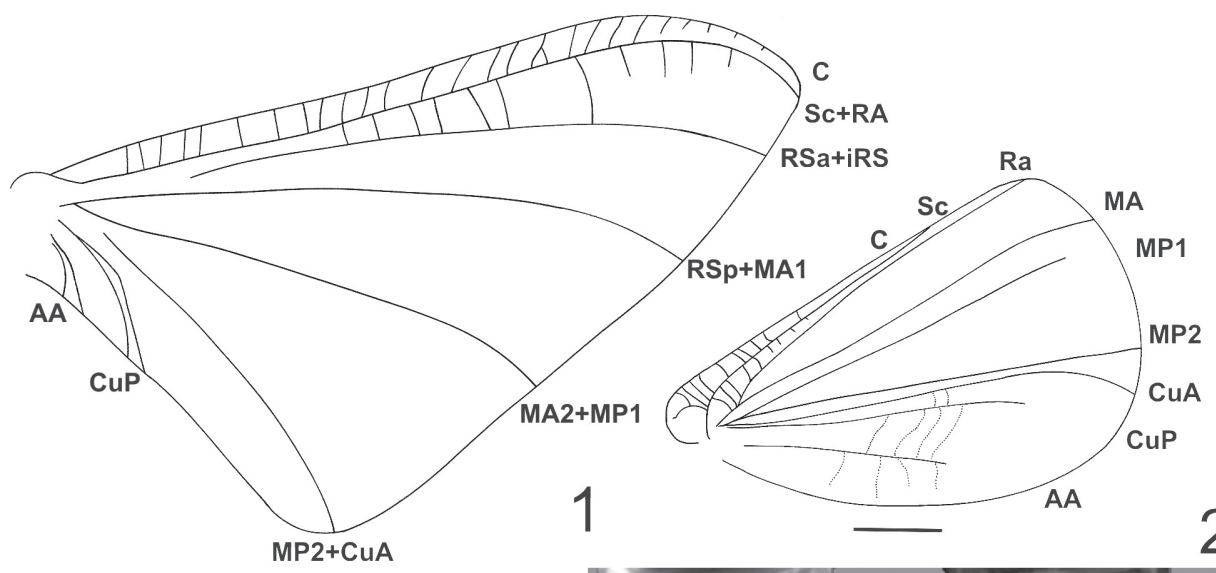

2
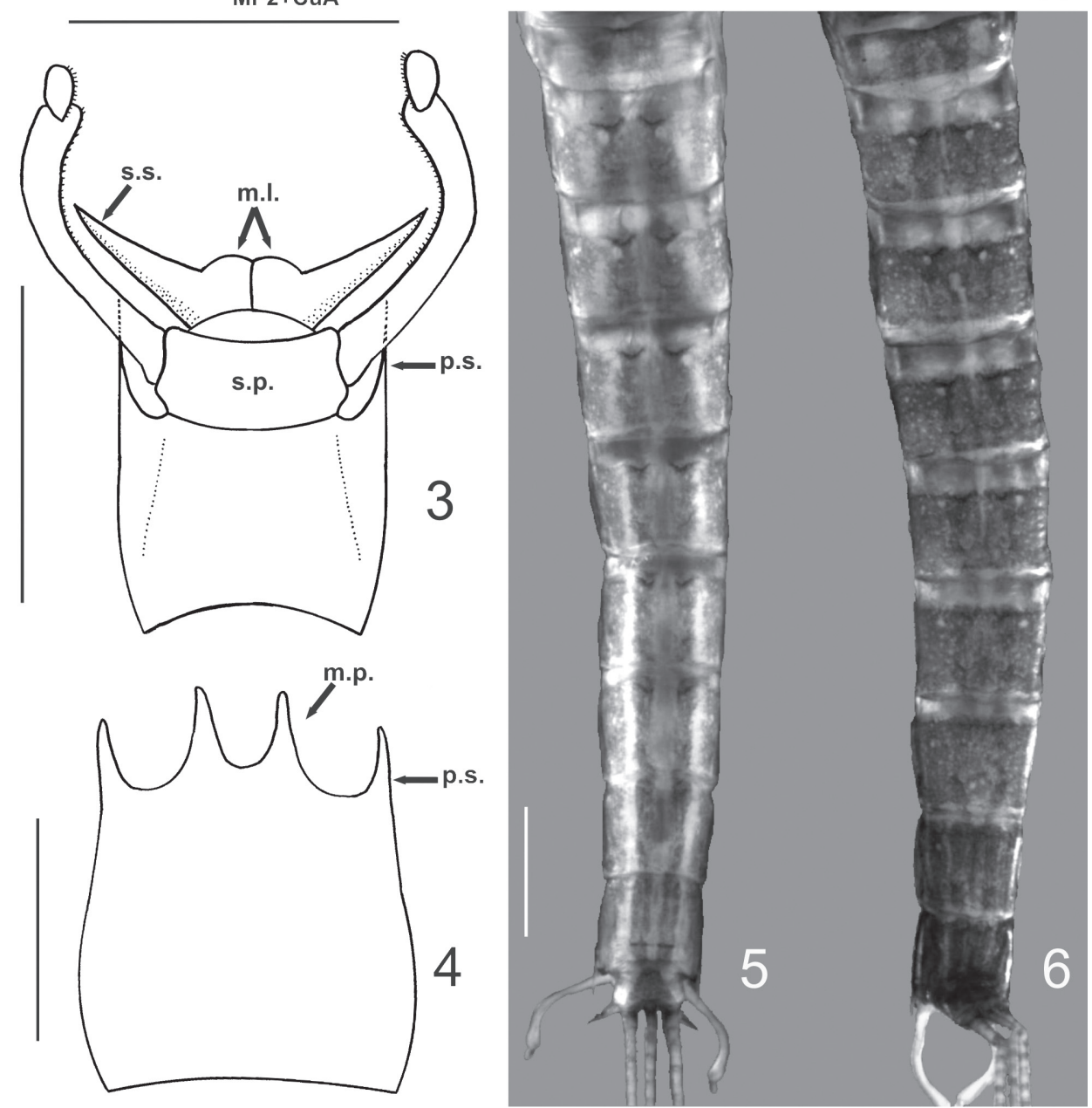

Fig. 1-6. Oligoneuria macabaiba sp. nov. male imago. 1. forewing; 2. hind wing; 3. male genitalia (ventral view); 4. female abdominal sternum IX (ventral view); 5. abdominal color pattern (dorsal view); 6. variation of abdominal color pattern, without longitudinal lines (dorsal view). Scale: $1.0 \mathrm{~mm}$ (m.l.=median lobes of penes, m.p.=median projection of female IX sternum, p.s.=posterolateral spines of abdomen, s.p.=styliger plate, and s.s.=sclerotized spine of penes). 
sternum IX medially projected, deeply cleft (Fig. 3). Caudal filaments brown, becoming whitish toward apex.

Variations: Length: body $16.0 \mathrm{~mm}-$ $18.7 \mathrm{~mm}$; fore wing $13.6 \mathrm{~mm}-15.0 \mathrm{~mm}$; hind wing $6.9 \mathrm{~mm}-8.0 \mathrm{~mm}$.

Type-material: Brazil, Rio de Janeiro: Macaé, Rio Macaé $\left(22^{\circ} 17^{\prime} 42.9^{\prime \prime} \mathrm{S}\right.$ 4152'48.0”'W), 16.iv.2009, Gonçalves I.C., Jardim G.A., Santos A.P.M., Alecrim V.P. \& Ferreira-Jr N. leg. One male imago (holotype; DZRJ629); same data, seven male imagos and five female imagos (DZRJ630); same data, two male imagos (DZRJ631); same data, one female imago (DZRJ632); Macaé, Rio São Pedro (2216'37.7” S - 41'52'22.8” W), 15.iv.2009, Gonçalves I.C., Jardim G.A., Santos A.P.M., Alecrim V.P. \& Ferreira-Jr N. leg. two female imagos (DZRJ627); Macaé, Cachoeiros de Macaé, Rio Macaé, $\left(22^{\circ} 25^{\prime} 49.5^{\prime \prime} \mathrm{S}\right.$ - 4118'06.0" W), 05.iv.2009, Gonçalves I.C., Jardim G.A., Sampaio B.H.L., Alecrim V.P., Dumas L.L. \& Nessimian J.L. leg. six female imagos (DZRJ628).

Etymology: the name "macabaiba" is an allusion to the macabaíba palm tree, whose fruit is called "maca-ê" a Tupi word that gave origin to the name Macaé, municipality where this species is found.

Biology: Imagos were found to fly mainly between six p.m. and seven p.m., before eight p.m. the swarm were over.

\section{DISCUSSION}

According to Kluge (2007), presence or absence of certain veins cannot be considered a distinguishing generic character since such differences exist on adults only. Oligoneuria macabaiba sp. nov. has no cross veins behind RSa+iRS nor has IMP but in the hind wing several faint cross veins can be seen after $\mathrm{CuA}$, corroborating Kluge's observations. Such feature appears to be species-specific since absence of IMP and cross veins after RSa+iRS was noticed on all specimens of $O$. macabaiba and O. itayana (according to Kluge, 2007). A phylogenetic revision of the genus is in preparation and will aid definition of the relations within the genus (F.F. Salles, pers. comm.).

Posterolateral spines on abdominal terga are described as "twisted" by Salles et al. (2007) and "crumpled" by Kluge (2007), but our specimens did not necessarily presented twisted or crumpled spines. In fact, the spines were found to be quite flexible, appearing twisted or not according to the individual. For this reason, we preferred to use the term "flexible" to better describe these spines. In O. macabai$b a$ sp. nov., posterolateral spines of segment II are represented by small projections but the spines on other segments are even longer than those in $O$. amazonica whereas in $O$. itayana a sexual dimorphism is described, with females having smaller spines than males (Kluge 2007).

O. macabaiba sp. nov. differs from other species of the genus by a distinctive characteristic: the pair of processes between forceps insertions. Such projections are present in $O$. itayana, O. amazonica and Oligoneurial f5=g6 sp.O5 draw by Kluge (2004) but are completely absent on $O$. macabaiba. In that sense, generic diagnosis should be expanded to comprise this trait.

Female sternum IX extends midposteriorly with a deep cleft, as seems to be common for the genus. In O. macabaiba sp. nov. and $O$. itayana these projections, as well as the abdominal posterolateral spines, appear to be longer than in $O$. amazonica. Male genitalia is distinctly different, with lack of projections on styliger plate and penes spines strongly divergent, oriented posterolaterally and broadly separated by two membranous lobes.

\section{ACKNOWLEDGMENTS}

We are thankful to members of Laboratório de Entomologia at Universidade Federal do Rio de Janeiro (UFRJ) from help on field trips and to the anonymous reviewers, for the valuable 
suggestions on the manuscript. This study was partially funded by CNPq and FAPERJ.

\section{RESUMEN}

En la Floresta Atlántica de Macaé, Rio de Janeiro, se describe una nueva especie del género Oligoneuria. La descripción fue basada en imagos machos y hembras de Oligoneuria macabaiba sp. nov. recolectados con trampas de luz. Estas especies presentan alas con venación y espinas abdominales posterolaterales similares al género, así como la expansión membranosa en la región anterior de la cabeza propia de Oligoneuria. Basado en las características de la nueva especie, el género es redefinido. La especie representa el primer registro del género para el Sudeste del Brasil.
Palabras clave: Neotrópicos, nuevo registro, nueva especie, Oligoneuriidae, América del Sur, taxonomía.

\section{REFERENCES}

Kluge, N. 2004. The phylogenetic system of Ephemeroptera. Kluwer Academic, Dordrecht, Netherlands.

Kluge, N. 2007. Oligoneuria itayana sp. n. (Ephemeroptera: Oligoneuriidae) - a new mayfly species from Peruvian Amazonia. Russ. Entomol. J. 16: 127-137.

Salles, F.F., M.S. Baptista, E.R. Da-Silva, N. Hamada \& J.E. Serrão. 2007. Redescription of the adults and description of the larvae and eggs of Oligoneurioides amazonicus Demoulin (Ephemeroptera: Oligoneuriidae). Aquat. Insect. 29: 139-149. 
